\title{
IN VITRO ANTIPLASMODIAL SCREENING OF ETHNOPHARMACOLOGICALLY SELECTED SOUTH AFRICAN PLANT SPECIES USED FOR THE TREATMENT OF MALARIA
}

\author{
Johanna Bapela, MSc; Marion Meyer, PHD; Marcel Kaiser
}

Corresponding Author: Ms. Johanna Bapela, MSc

Corresponding Author's Institution: University of Pretoria

\begin{abstract}
:
Ethnopharmacological relevance: The investigated plant species are traditionally used by Venda people of South Africa, in the treatment of malaria and associated symptoms.
\end{abstract}

Aim of the study: To evaluate the in vitro antiplasmodial efficacy and cytotoxic properties of indigenous medicinal plants used by Venda people against malaria.

Materials and methods: In vitro antiplasmodial activity and cytotoxic properties were evaluated on twenty indigenous plant species. Ground plant material was extracted in dichloromethane: 50\% methanol (1:1). Antiplasmodial activity was evaluated against the chloroquine-sensitive strain of Plasmodium falciparum (NF54). The cytotoxicity of the plant extracts were assessed against mammalian L-6 rat skeletal myoblast cells. The selectivity index (SI) values were then calculated.

Results: Of the 43 plant extracts evaluated, 10 exhibited pronounced antiplasmodial activity $\left(\mathrm{IC}_{50} \leq 5 \mu \mathrm{g} / \mathrm{ml}\right)$ with good therapeutic indices $(\mathrm{SI} \geq 10)$. Lipophilic plant extracts were relatively more potent than polar extracts. Tabernaemontana elegans Stapf. (Apocynaceae) and Vangueria infausta Burch. subsp. infausta (Rubiaceae) extracts displayed significant antiplasmodial activity $\left(\mathrm{IC}_{50}<2 \mu \mathrm{g} / \mathrm{ml}\right)$.

Conclusion: Findings of this study partly support the ethnomedical use of the investigated plant species by Venda people as antimalarial remedies. The study also highlights some of the knowledge gaps that require further phytochemical studies on the specified plant species.

\section{Keywords:}

Antiplasmodial activity; Medicinal plants; Malaria; Plasmodium falciparum 
GRAPHICAL ABSTRACT

\begin{tabular}{|c|c|c|c|c|}
\hline Plant species & $\begin{array}{l}\text { Extraction } \\
\text { solvent }\end{array}$ & $\begin{array}{l}\text { Antiplasmodial } \\
\text { activity (Pf-NF54) }\end{array}$ & $\begin{array}{l}\text { Cytotoxicity } \\
\text { (L6-cells) }\end{array}$ & $\begin{array}{l}\text { Selectivity } \\
\text { Index }\end{array}$ \\
\hline $\begin{array}{l}\text { Albizia versicolor Welw. ex Oliv. } \\
\text { (Fabaceae) }\end{array}$ & DCM & 2.12 & 55.1 & 26 \\
\hline $\begin{array}{l}\text { Bridelia mollis Hutch. } \\
\text { (Phyllanthaceae) }\end{array}$ & DCM & 3.06 & 51.4 & 17 \\
\hline $\begin{array}{c}\text { Capparis tomentosa Lam. } \\
\text { (Capparidaceae) }\end{array}$ & DCM & 2.19 & 40.8 & 19 \\
\hline $\begin{array}{c}\text { Cussonia spicata Thunb. } \\
\text { (Araliaceae) }\end{array}$ & DCM & 3.25 & 47.8 & 15 \\
\hline $\begin{array}{l}\text { Dichrostachys cinerea Wight et Arn. } \\
\text { (Fabaceae) }\end{array}$ & DCM & 2.10 & 51.6 & 25 \\
\hline $\begin{array}{l}\text { Rauvolfia caffra Sond. } \\
\text { (Apocynaceae) }\end{array}$ & DCM & 2.13 & 26.9 & 13 \\
\hline $\begin{array}{l}\text { Tabernaemontana elegans Stapf. } \\
\text { (Apocynaceae) }\end{array}$ & DCM & 0.33 & 4.68 & 14 \\
\hline T. elegans & $\mathrm{MeOH}: \mathrm{H}_{2} \mathrm{O}$ & 0.83 & 38.2 & 46 \\
\hline $\begin{array}{l}\text { Vangueria infausta Burch. subsp. } \\
\text { infausta (Rubiaceae) }\end{array}$ & DCM & 1.84 & 45.7 & 25 \\
\hline $\begin{array}{l}\text { Xylopia parviflora (A.Rich.) Benth. } \\
\text { Oliv. (Annonaceae) }\end{array}$ & DCM & 2.19 & 51.5 & 24 \\
\hline Chloroquine & & 0.003 & & \\
\hline Podophyllotoxin & & & 0.007 & \\
\hline
\end{tabular}




\section{Introduction}

Despite the significant advances made in lessening the burden of malaria in recent years, the disease still remains a major public health problem affecting many people in tropical and subtropical regions (Murray et al., 2012). This is especially the case in sub-Saharan Africa where $90 \%$ of the estimated annual global malaria deaths occur (World Health Organization, 2013). Most of the conventional drugs are no longer effective due to the emergence of drug resistant strains. Additionally, some of the indispensable drugs that are still effective suffer from problems related to toxicity, prolonged treatment schedules, variable responses between strains, noncompliance by patients and inaccessibility to proper health facilities (Olasehinde et al., 2012). These factors combined with the absence of effective vaccines highlight the need for new chemotherapeutic agents with novel modes of action that may alleviate the burden of malaria. In our search for novel antimalarial plant products (Prozesky et al., 2001; Tetyana et al., 2002; Adelekan et al., 2008), twenty indigenous plant species used to treat malaria and/or malarial symptoms by Venda people, were evaluated for their antiplasmodial efficacy. We report here on the preliminary results of the study.

\section{Materials and methods}

\subsection{Plant collection}

An ethnobotanical survey and a chemotaxomic approach were followed to select and collect indigenous plant species used to treat malaria and its symptoms by Venda people. The selection of medicinal plants investigated in this study was based on informal interviews with Venda people living in Mutale Municipality of Limpopo Province. Main questions asked were; which local plants are used in cases of malaria or its related symptoms, plant parts harvested for such purposes and where are they collected. The data was gathered from Venda people and from published literature. In cases where the locally used plant species was not documented in ethnopharmacological data, the plant was not harvested. Likewise, if plants were documented in literature, and not used locally, it was not collected for this study. Plant samples from the selected twenty species (Table 1.) were collected and voucher specimens were identified and deposited at the H.G.W.J. Schweickerdt Herbarium of the University of Pretoria. 
Table 1. Plant species evaluated for antiplasmodial activity, their ethnomedicinal uses against malaria (Bandeira et al., 2001; Mabogo, 1990; Watt and Breyer-Brandwijk, 1962), antiplasmodial activity, cytotoxicity and selectivity indices. IC $\mathrm{C}_{50}$ values are expressed as a mean value of two independent assays and were recorded in $\mu \mathrm{g} / \mathrm{ml}$.

\begin{tabular}{|c|c|c|c|c|c|}
\hline Plant species and voucher number & Ethnomedicinal uses & $\begin{array}{l}\text { Plant part used } \\
\text { (DCM: } 50 \% \mathrm{MeOH})\end{array}$ & $\begin{array}{l}\text { IC }_{50 \text { (parasite) }} \\
\quad(\text { Pf-NF54) }\end{array}$ & $\begin{array}{l}\text { IC }_{50 \text { (mammalian cell) }} \\
\text { (L6-cells) }\end{array}$ & $\begin{array}{l}{ }^{a} \text { Selectivity } \\
\text { Index }\end{array}$ \\
\hline $\begin{array}{l}\text { Albizia versicolor Welw. ex Oliv. } \\
\text { (Fabaceae) }\end{array}$ & \multirow{2}{*}{$\begin{array}{l}\text { Root and stem bark are used as } \\
\text { ingredients to prepare a polyherbal } \\
\text { decoction taken against malaria }\end{array}$} & Roots & $2.12 / 23.8$ & $55.1 / 42.0$ & $26.0 / 1.76$ \\
\hline Mutambapfunda, 120322 & & Stem bark & $7.08 / 27.3$ & $72.1 / 52.3$ & $10.18 / 1.92$ \\
\hline $\begin{array}{l}\text { Anthocleista grandiflora Gilg. } \\
\text { (Loganiaceae) } \\
\text { Mueneene, } 120323\end{array}$ & $\begin{array}{l}\text { A decoction of the stem bark and } \\
\text { leaves is administered in cases of } \\
\text { malaria }\end{array}$ & Stem bark & $8.69 />50$ & $55.6 / 70.1$ & $6.40 /$ n.d. \\
\hline $\begin{array}{l}\text { Bridelia mollis Hutch. } \\
\text { (Phyllanthaceae) } \\
\text { Mukumbakumba, } 120324\end{array}$ & $\begin{array}{l}\text { Root infusion from a closely related } \\
\text { plant species, } B \text {. micrantha, is used } \\
\text { against malaria-related fevers }\end{array}$ & Roots & $3.06 / 28.5$ & $51.4 / 49.6$ & $16.8 / 24.6$ \\
\hline $\begin{array}{l}\text { Capparis tomentosa Lam. } \\
\text { (Capparidaceae) } \\
\text { Moubadali, } 120325\end{array}$ & $\begin{array}{l}\text { Root decoction is drunk as an } \\
\text { antipyretic in the treatment of malaria }\end{array}$ & Roots & $2.19 / 29.2$ & $40.8 / 70.4$ & $18.6 / 2.41$ \\
\hline $\begin{array}{l}\text { Clematis brachiata Thunb. } \\
\text { (Ranunculaceae) } \\
\text { Tshiumbeumbe, } 120326\end{array}$ & $\begin{array}{l}\text { Hot root decoction is used for } \\
\text { steaming or taken orally for malaria } \\
\text { and colds }\end{array}$ & Roots & $5.36 />50$ & $42.6 / 72.3$ & $7.95 /$ n.d. \\
\hline $\begin{array}{l}\text { Clerodendrum glabrum E. Mey. } \\
\text { (Verbenaceae) } \\
\text { Umnukalembeba,120327 }\end{array}$ & $\begin{array}{l}\text { Leaf infusion is taken as a remedy for } \\
\text { fevers associated with malaria }\end{array}$ & Leaves & $8.89 />50$ & $62.2 / 72.7$ & $3.02 /$ n.d. \\
\hline $\begin{array}{l}\text { Cussonia spicata Thunb. } \\
\text { (Araliaceae) } \\
\text { Musenzhe, } 120328\end{array}$ & $\begin{array}{l}\text { A root infusion made from a handful } \\
\text { of roots are used as emetics for } \\
\text { fevers }\end{array}$ & Root bark & $3.25 />50$ & $47.8 / 69.1$ & 14.7 / n.d. \\
\hline
\end{tabular}




\begin{tabular}{|c|c|c|c|c|c|}
\hline $\begin{array}{l}\text { Dichrostachys cinerea Wight et Arn. } \\
\text { (Fabaceae) } \\
\text { Murenzhe, } 120329\end{array}$ & $\begin{array}{l}\text { Crushed roots are soaked in water } \\
\text { and administered in cases of } \\
\text { febrifuge }\end{array}$ & Roots & $2.10 />50$ & $51.6 / 65.3$ & 24.6 / n.d. \\
\hline $\begin{array}{l}\text { Diospyros mespiliformis Hochst. ex A.DC. } \\
\text { (Ebenaceae) } \\
\text { Musuma, } 129330\end{array}$ & $\begin{array}{l}\text { Root decoction is used to alleviate } \\
\text { febrile symptoms }\end{array}$ & Roots & $4.40 / 28.4$ & $24.3 / 60.4$ & $5.52 / 2.13$ \\
\hline $\begin{array}{l}\text { Pappea capensis Eckl. \& Zeyh. } \\
\text { (Sapindaceae) } \\
\text { Tshikavhavhe, } 120331\end{array}$ & $\begin{array}{l}\text { Branches are boiled and taken as tea } \\
\text { for malaria }\end{array}$ & Twigs & $5.47 / 24.8$ & $54.0 / 55.2$ & $9.87 / 2.23$ \\
\hline $\begin{array}{l}\text { Parinari curatellifolia Planch. Ex Benth. } \\
\text { (Rosaceae) } \\
\text { Muvhula, } 120332\end{array}$ & $\begin{array}{l}\text { Stem bark soaked together with other } \\
\text { plant species are used for the } \\
\text { treatment of malaria }\end{array}$ & Stem bark & $6.99 / 16.9$ & $57.6 / 55.4$ & $8.24 / 3.28$ \\
\hline $\begin{array}{l}\text { Pyrenacantha grandiflora Baill. } \\
\text { (Icacinaceae) } \\
\text { Bwere, } 120333\end{array}$ & $\begin{array}{l}\text { A decoction prepared from powdered } \\
\text { roots is used for malaria }\end{array}$ & Roots & $5.82 />50$ & $0.52 / 10.5$ & 0.089 / n.d. \\
\hline $\begin{array}{l}\text { Rauvolfia caffra Sond. } \\
\text { (Apocynaceae) } \\
\text { Munadzi, } 120334\end{array}$ & $\begin{array}{l}\text { Used as a substitute for T. elegans } \\
\text { (of the same family) to treat malaria } \\
\text { and fevers }\end{array}$ & Stem bark & $2.13 / 10.8$ & $26.9 / 57.2$ & $12.6 / 5.30$ \\
\hline $\begin{array}{l}\text { Senna petersiana (Bolle) Lock. } \\
\quad \text { (Fabaceae) } \\
\text { Munembenembe, } 120335\end{array}$ & $\begin{array}{l}\text { Leaf infusion are taken as tea for } \\
\text { malaria }\end{array}$ & Leaves & $22.5 / 22.1$ & $59.3 / 66.8$ & 2.64 / 3.02 \\
\hline $\begin{array}{l}\text { Syzygium cordatum Hochst. } \\
\text { (Myrtaceae) } \\
\text { Mutu, } 120336\end{array}$ & $\begin{array}{l}\text { Leaf infusions administered for } \\
\text { febrifuge and headaches related to } \\
\text { malaria }\end{array}$ & Leaves & $6.15 / 10.4$ & $65.7 / 53.8$ & $10.68 / 5.17$ \\
\hline Tabernaemontana elegans Stapf. & Stem bark and root decoctions are & Stem bark & $0.331 / 0.834$ & $4.68 / 38.2$ & $14.1 / 45.8$ \\
\hline
\end{tabular}




\begin{tabular}{|c|c|c|c|c|c|}
\hline $\begin{array}{l}\text { ( Apocynaceae) } \\
\text { Muhatu, } 120337\end{array}$ & used for febrifuge and malaria & & & & \\
\hline $\begin{array}{l}\text { Vangueria infausta Burch. subsp. infausta } \\
\text { (Rubiaceae) } \\
\text { Muzwilu, } 120338\end{array}$ & $\begin{array}{l}\text { Infusions made from the roots and } \\
\text { leaves is taken orally to treat malaria }\end{array}$ & Roots & $1.84 />50$ & $45.7 / 71.5$ & $24.8 /$ n.d. \\
\hline $\begin{array}{l}{ }^{\mathbf{b}} \text { Ximenia americana Linn. } \\
\text { (Olacaceae) } \\
\text { Muthanzwa, } 120339\end{array}$ & $\begin{array}{l}\text { Root infusions are taken for febrifuge } \\
\text { and ground root powder is applied } \\
\text { topically for febrile headaches }\end{array}$ & Roots & 28.2 & 69.1 & 2.45 \\
\hline $\begin{array}{l}\text { Ximenia caffra Sond. } \\
\text { (Olacaceae) } \\
\text { Mutshili, } 120340\end{array}$ & $\begin{array}{l}\text { Powdered leaves and twigs are used } \\
\text { for fevers and febrifuge }\end{array}$ & Leaves & $3.01 />50$ & $8.68 />50$ & $2.88 /$ n.d. \\
\hline $\begin{array}{l}\text { Xylopia parviflora (A.Rich.) Benth. Oliv. } \\
\text { (Annonaceae) } \\
\text { Muvhulavhusika, } 120341\end{array}$ & $\begin{array}{l}\text { Hot root decoctions are used as } \\
\text { emetics for fevers }\end{array}$ & Roots & $2.19 / 14.2$ & $51.5 / 78.3$ & $23.5 / 5.51$ \\
\hline Chloroquine & & 0.003 & & & \\
\hline Podophyllotoxin & & & 0.007 & & \\
\hline
\end{tabular}

DCM: Dichloromethane, 50 \% MeOH: Methanol and distilled water (1:1)

Pf-NF54: Plasmodium falciparum NF54 strain

L6-cells: Rat skeletal myoblast L6 cell line

${ }^{a}$ Selectivity index $(\mathrm{SI})$ : quotient of $\mathrm{IC}_{50}$ in $\mathrm{L} 6$ cells and $\mathrm{IC}_{50}$ against parasites

${ }^{b}$ Ximenia americana did not result in two phases between the DCM and $50 \% \mathrm{MeOH}$

n.d.: not determined 


\subsection{Extraction of plant samples}

For each plant sample, $20 \mathrm{~g}$ of dried ground plant material was repeatedly extracted in $300 \mathrm{ml}$ of dichloromethane: $50 \%$ methanol (1:1) and then filtered. The recovered filtrate was then separated. Non-polar fractions were concentrated under vacuum at $30{ }^{\circ} \mathrm{C}$. Methanol in the polar fractions was vaporized at $40{ }^{\circ} \mathrm{C}$ and the resulting aqueous extracts were freeze-dried using a bench top manifold freeze dryer (Virtis). Dichloromethane and aqueous crude extracts were analysed independently.

\subsection{In vitro antiplasmodial assay}

In vitro activity of the acquired plant extracts (43) was determined following a $\left[{ }^{3} \mathrm{H}\right]$ hypoxanthine incorporation assay using chloroquine sensitive (NF54) strain of Plasmodium falciparum as the test organism (Matile and Pink, 1990). Plant extracts were dissolved in DMSO at $10 \mathrm{mg} / \mathrm{ml}$ and added to parasite cultures incubated in RPMI 1640 medium without hypoxanthine, supplemented with HEPES (5.94 g/l), $\mathrm{NaHCO}_{3}(2.1 \mathrm{~g} / \mathrm{l})$, neomycin $(100 \mathrm{U} / \mathrm{ml})$, AlbumaxR $(5 \mathrm{~g} / \mathrm{l})$ and washed human red cells $\mathrm{A}+$ at $2.5 \%$ haematocrit. Chloroquine (Sigma) was used as the standard drug. Serial drug dilutions of eleven 3-fold dilution steps were prepared. The 96 -well plates were incubated in a humidified atmosphere at $37{ }^{\circ} \mathrm{C}, 4 \% \mathrm{CO}_{2}, 3 \% \mathrm{O}_{2}$ and $93 \% \mathrm{~N}_{2}$. After $48 \mathrm{~h} 50 \mu \mathrm{l}$ of [ $\left.{ }^{3} \mathrm{H}\right]$ hypoxanthine was added to each well. Plates were incubated for a further $24 \mathrm{~h}$ and then harvested with a Betaplate ${ }^{\mathrm{TM}}$ cell harvester (Wallac). Red blood cells were transferred onto a glass fibre filters, washed and the dried filters were then inserted into a plastic foil and counted in a Betaplate ${ }^{\mathrm{TM}}$ liquid scintillation counter (Wallac). $\mathrm{IC}_{50}$ values were calculated from sigmoidal inhibition curves by linear regression using Microsoft Excel (Huber and Koella, 1993).

\subsection{Cytotoxicity assay}

The antiproliferative activity of plant extracts was assessed on rat skeletal myoblasts L-6 cells (Ahmed et al., 1994). Assays were performed in 96-well microtiter plates, each well containing $100 \mu \mathrm{l}$ of RPMI 1640 medium supplemented with $1 \%$ L-glutamine $(200 \mathrm{mM}), 10 \%$ fetal bovine serum and $4000 \mathrm{~L}-6$ cells. Podophyllotoxin was used as a control. Serial drug dilutions with a range of 100 to $0.002 \mu \mathrm{g} / \mathrm{ml}$ were conducted. After 70 hours of incubation the plates were inspected under an inverted microscope. $10 \mu \mathrm{l}$ of Alamar was then added to each well and the plates were incubated for another 2 hours. The plates were then read with a 
Spectramax Gemini XS microplate fluorometer (Molecular Devices Cooperation). The $\mathrm{IC}_{50}$ values were calculated as in 2.2 .

\section{Results and discussion}

The inhibitory concentration $\left(\mathrm{IC}_{50}\right)$ and selectivity index $(\mathrm{SI})$ values of plant extracts that demonstrated significant antiplasmodial activity (IC $50 \leq 5 \mu \mathrm{g} / \mathrm{ml}$ ) when tested against the chloroquine sensitive strain of $P$. falciparum (NF54) are shown in Table 1. Selectivity index (SI) values were calculated by dividing the $I_{50}$ value for the cytotoxicity by the $\mathrm{IC}_{50}$ value of antiplasmodial activity. It is generally considered that the antimalarial efficacy of a given plant extract is not due to the in vitro cytotoxicity when the $S I \geq 10$, therefore displaying selective antiplasmodial activity (Vonthron-Senecheau et al., 2003). For the purpose of this study, a plant extract was considered to be a potential hit for drug discovery when the $\mathrm{IC}_{50}$ was $\leq 5 \mu \mathrm{g} / \mathrm{ml}$ and an SI value of $\geq 10$ could be established. Of all the 43 extracts assayed, $23 \%$ exhibited pronounced selective antiplasmodial activity.

Tabernaemontana elegans was the best candidate, as both the dichloromethane and polar extracts from its stem bark inhibited plasmodial growth at $\mathrm{IC}_{50}=0.33$ and $\mathrm{IC}_{50}=$ $0.83 \mu \mathrm{g} / \mathrm{ml}$, respectively. With respective SI values of 14 and 46 , these extracts were considered to be non-toxic to rat skeletal myoblast L6 cells. Despite the wide ethnomedical use of $T$. elegans as an antimalarial remedy (Bandeira et al., 2001), this is the first study to document its significant antiplasmodial activity. Studies conducted by Ramalhete et al., 2008 revealed moderate or no significant activity of polar leaf extracts from the same plant species. Nevertheless, studies conducted on indole alkaloids from a closely related species, $T$. sessilifolia, showed some good antiplasmodial activity (Girardot et al., 2012), which could explain the observed bioactivity.

Dichloromethane root extract of Vangueria infausta subsp. infausta showed a marked inhibitory effect $\left(I \mathrm{C}_{50}=1.84 \mu \mathrm{g} / \mathrm{ml}, \mathrm{SI}=25\right)$ against $P$. falciparum. A study conducted on chloroform root bark extract from $V$. infausta subsp. infausta significantly inhibited two strains of $P$. falciparum at $\mathrm{IC}_{50}$ of 3.80 and $4.50 \mu \mathrm{g} / \mathrm{ml}$ (Abosi et al., 2006). Further studies are needed to determine the compounds responsible for the observed antiplasmodial activity. Chloroquine-sensitive strain of $P$. falciparum was found to be susceptible to the lipophilic extracts of Albizia 
versicolor, Capparis tomentosa, Dichrostachys cinerea, Rauvolfia caffra and Xylopia parviflora at concentrations ranging from 2.10 to $2.19 \mu \mathrm{g} / \mathrm{ml}$ and SI values ranging between 12 and 26 .

Although Albizia species are well documented for their strong in vitro as well as in vivo antimalarial activities (Samoylenko et al., 2009), reports on $A$. versicolor are lacking. Clarkson et al. (2004) detected a weak antiplasmodial activity $\left(\mathrm{IC}_{50}=38\right.$ $\mu \mathrm{g} / \mathrm{ml}$ ) in the dichloromethane root extract $C$. tomentosa, which is relatively low compared to the results $\left(\mathrm{IC}_{50}=2.19 \mu \mathrm{g} / \mathrm{ml}\right)$ found in this study. An ethanol leaf extract from $D$. cinerea showed no activity at the highest concentration $(5 \mu \mathrm{g} / \mathrm{ml})$ tested (Atindehou, 2004). Results from the current study do not support the relatively low antiplasmodial activity $\left(\mathrm{IC}_{50} \geq 10 \mu \mathrm{g} / \mathrm{ml}\right)$ reported previously for $R$. caffra (Clarkson et al., 2004). Boyom et al. (2011) reported on the potency of methanol leaf and stem extracts of $X$. parviflora from Cameroon. In agreement with the results obtained in this study, these extracts showed high in vitro antiplasmodial activity (IC $50 \leq 5 \mu \mathrm{g} / \mathrm{ml})$.

The non-polar root extracts of Bridelia mollis and Cussonia spicata demonstrated significant in vitro antiplasmodial activity $\left(\mathrm{IC}_{50} \sim 3 \mu \mathrm{g} / \mathrm{ml}\right)$ and selectivity for malaria parasite with SI values of 17 and 15, respectively. In South Africa, B. mollis is traditionally used as an antiparasitic against worms, among other uses, while a closely related species, $B$. micrantha is used against malaria-related fevers (Watt and Breyer-Brandwijk, 1962; Mabogo, 1990). Literature data on the biological activity and phytochemical constituents of $B$. mollis is limited. The genus Cussonia has been extensively studied for its antiplasmodial properties, and the polar bark extracts of $C$. spicata were reported to have a relatively weak activity (De Villiers et al., 2010). Results obtained in this study are consistent with those reported for other members of the same family, when extracted with non-polar solvent (Clarkson et al., 2004). Although most of the investigated plant species have been previously tested against $P$. falciparum, data on the compounds attributable to their respective antiplasmodial activity is very limited.

It is worth noting that antimalarial activity was mainly found in lipophilic plant extracts, which confirm earlier reports that dichloromethane extracts generally have a higher antiplasmodial activity than methanol and aqueous extracts (Irungu et al., 2007). Several species that were strongly associated with the treatment of malaria by Venda people and which are cited in ethnobotanical literature demonstrated weak 
antimalarial activity in this study. Thus, traditional remedies that are inactive against the Plasmodium asexual erythrocytic stage may be active against the hepatocyte phase, thereby preventing infection of red blood cells (Mesia et al., 2010). Investigations into treatments for malaria should therefore be directed at targeting the various stages of Plasmodium life-cycle and other clinical symptoms related to the disease state (Rasoanaivo et al., 2011).

\section{Conclusions}

The findings of this study give a measure of credibility to the ethnomedical use of the investigated plant species by Venda people and to the rationale of an ethnopharmacological approach when bioprospecting medicinal plants for antiplasmodial lead compounds. Further phytochemical analyses are currently underway in an attempt to fractionate, isolate and identify the active constituents in extracts that demonstrated significant bioactivity.

\section{Acknowledgements}

National Research Fund is acknowledged for providing the financial assistance for the study. The authors are grateful to the Swiss Tropical and Public Health Institute for the collaborative work on antiprotozoal studies. Dr. $\mathrm{H}$ Heyman is thanked for his contribution in the study.

\section{References}

Abosi, A.O., Mbukwa, E., Majinda, R.R., Raseroka, B.H., Yenesew, A., Midiwo, J.O., Akala, H., Liyala, P., Waters, N.C., 2006. Vangueria infausta root bark: in vivo and in vitro antiplasmodial activity. British Journal of Biomedical Science: 129-133.

Adelekan, A.M., Prozesky, A.E., Hussein, A.A., Ureña, L.D., Van Rooyen, P.H., Liles, D.C., Meyer, J.J.M., Rodríguez, B., 2008. Bioactive diterpenes and other constituents of Croton steenkampianus. Journal of Natural Products 71: 1919-1922.

Ahmed, S.A., Gogal, R.M., Walsh, J.E., 1994. A new rapid and simple nonradioactive assay to monitor and determine the proliferation of lymphocytes: an alternative to $\left[{ }^{3} \mathrm{H}\right]$ thymidine incorporation assay. Journal of Immunological Methods 
Atindehou, K., Schmid, C., Brun, R., Koné, M.W., Traore, D., 2004. Antitrypanosomal and antiplasmodial activity of medicinal plants from Côte d'Ivoire. Journal of Ethnopharmacology 90: 221-227.

Bandeira, S.O., Gaspar, Pagula, F.P., 2001. African Healthcare: Emphasis on Mozambique. Pharmaceutical Biology 39: 70-73.

Boyom, F.F., Fokou, P.V.T., Yamthe, L.R.T., Mfopa, A.N., Kemgne, E.M., Mbacham, W.F., Tsamo, E., Zollo, P.H.A., Gut, J., Rosenthal, P.J., 2011. Potent antiplasmodial extracts from Cameroonian Annonaceae. Journal of Ethnopharmacology 134: 717724.

Clarkson, C., Maharaj, V.J., Crouch, N.R., Grace, O.M., Pillay, P., Matsabisa, M.G., Bhagwandhin, N., Smith, P.J., Folb, P.I., 2004. In vitro antiplasmodial activity of medicinal plants native to or naturalized in South Africa. Journal of Ethnopharmacology 92: 177-191.

De Villiers, B.J., Van Vuuren, S.F., Van Zyl, R.L., Van Wyk, B.-E., 2010. Antimicrobial and antimalarial activity of Cussonia species (Araliaceae). Journal of Ethnopharmacology 129: 189-196.

Girardot, M., Deregnaucourt, C., Deville, A., Dubost, L., Joyeau, R., Allorge, L., Rasoanaivo, P., Mambu, L., 2012. Indole alkaloids from Muntafara sessilifolia with antiplasmodial and cytotoxic activities. Phytochemistry 73: 65-73.

Huber, W., Koella, J.C., 1993. A comparison of the three methods of estimating $\mathrm{EC}_{50}$ in studies of drug resistance of malaria parasites. Acta Tropica 55: 257-261. 
Irungu, B.N., Rakunga, G.M., Mungai, G.M., Muthaura, C.N., 2007. In vitro antiplasmodial and cytotoxicity activities of 14 medicinal plants from Kenya. South African Journal of Botany 73: 204-207.

Mabogo, D.E.N., 1990. The Ethnobotany of the Vhavenda. Unpublished MSc. Thesis, University of Pretoria, Pretoria.

Matile, H., Pink, J. R. L., 1990. Plasmodium falciparum malaria parasite cultures and their use in immunology: In Lefkovits, I., Pernis, B., (Eds.), Immunological Methods. Academic Press, San Diego.

Mesia, K., Cimanga, R.K., Dhooghe, L., Cos, P., Apers, S., Totte, J., Tona, G., Pieters, L., Vlietnick, A.J., Maes, L., 2010. Antimalarial activity and toxicity evaluation of a quantified Nauclea pobeguinii extract. Journal of Ethnopharmacology 131: 1016.

Murray, C.J.L., Rosenfeld, L.C., Lim, S.S., Andrews, K.G., Foreman, K.J., Haring, D., Fullman, N., (...), Lopez, A.D., 2012. Global malaria mortality between 1980 and 2010: A systematic analysis: The Lancet 379: 413-431.

Olasehinde, G.I., Yah, C.S., Singh, R., Ojuronbge, O.O., Ajayi, A.A., Valecha, N., Abolaji, A.O., Adeyeba, A.O., 2012. Genetic diversity of Plasmodium falciparum field isolates from south Western Nigeria. African Health Sciences 12 (3): 355-361.

Prozesky, E.A., Meyer, J.J.M., Louw, A.I., 2001. In vitro antiplasmodial activity and cytotoxicity of ethnobotanically selected South African plants. Journal of Ethnopharmacology 76: 239-245.

Rasoanaivo, P., Wright, C.W., Willcox, M.L., Gilbert, B., 2011. Whole plant extracts versus single compounds for the treatment of malaria: synergy and positive interactions. Malaria Journal 10: 54. 
Ramalhete, C., Lopes, D., Mulhovo, S., Rosário, V.E., Ferreira, M.J.U., 2008. Antimalarial activity of some plants traditionally used in Mozambique. Workshop Plantas Medicinais e Fitoterapêuticas nos Trópicos.

Samoylenko, V., Jacob, M.R., Khan, S.I., Zhao, J., Tekwani, B.L., Midiwo, J.O., Walker, L.A., Muhammad, I., 2009. Antimicrobial, antiparasitic and cytotoxic spermine alkaloids from Albizia schimperiana. Natural Product Communications 4: 791-796.

Tetyana, P., Prozesky, E.A., Jäger, A.K., Meyer, J.J.M., Van Staden, J., 2002. Some medicinal properties of Cussonia and Schefflera species used in traditional medicine. South African of Journal of Botany 68: 51-54.

Vonthron-Senecheau, C., Weniger, B., Quattara, M., Tra Bi, F., Kamenan, A., Lobstein, A., Brun, R., Anton, R., 2003. In vitro antiplasmodial activity and cytotoxicity of ethnobotanically selected Ivorian plants. Journal of Ethnopharmacology 87: 221-225.

Watt, J.M., Breyer-Brandwijk, M.G., 1962. The Medicinal and Poisonous Plants of Southern and Eastern Africa, second edition, Livingstone, London.

World Health Organization (2013). Factsheet on the World Malaria Report. http://www.who.int/malaria/media/world malaria report 2013/en/ (accessed 12.07.2014). 